\title{
Cell or Vector Cryopreservation
}

National Cancer Institute

\section{Source}

National Cancer Institute. Cell or Vector Cryopreservation. NCI Thesaurus. Code C112963.

Preservation of cells or genetic vectors by storage at low temperatures. 